\title{
A 6-Hour Nocturnal Interruption of a Continuous Subcutaneous Insulin Infusion: 2. Marked Attenuation of the Metabolic Deterioration by Somatostatin
}

\author{
A. J. Scheen, G. Krzentowski, M. Castillo, P.J. Lefèbvre and A. S. Luyckx \\ Division of Diabetes and Division of Clinical Pharmacology, Institute of Medicine, University of Liège, Liege, Belgium
}

\begin{abstract}
Summary. We investigated the respective roles of insulin deprivation and counter-regulatory hormones in the metabolic deterioration after a nocturnal interruption of continuous subcutaneous insulin infusion in Type 1 (insulin-dependent) diabetic patients without residual insulin secretion. Changes in blood glucose, plasma non-esterified fatty acids, 3-hydroxybutyrate, glucagon, growth hormone, cortisol and free insulin in seven patients whose pumps were deliberately stopped between $23.00 \mathrm{~h}$ and $05.00 \mathrm{~h}$ were compared in two randomized tests carried out either during an intravenous somatostatin infusion at a constant rate of $250 \mu \mathrm{g} / \mathrm{h}$ from $22.00 \mathrm{~h}$ until $07.00 \mathrm{~h}$ (somatostatin test) or during a saline infusion (control test). Arrest of the pumps resulted in a rapid (already significant after $1 \mathrm{~h}$ ) and progressive (nadir after 5-6 h) decrease in plasma free insulin concentrations with no statistically significant differences between the two tests. Somatostatin remarkably depressed basal levels of growth hormone and the late significant increase in glucagon $(+39 \pm 14 \mathrm{pg} / \mathrm{ml}$ at $05.00 \mathrm{~h}, 2 p<$ 0.05 ) observed during the control test. In contrast, cortisol secretion was not inhibited. The sharp linear increase in blood glucose observed from 01.00 to $05.00 \mathrm{~h}\left(38 \pm 4 \mu \mathrm{mol} \cdot 1^{-1}\right.$. $\min ^{-1}$ ) in the control test was fully suppressed with a paradoxical tendency to hypoglycaemia until $03.00 \mathrm{~h}$ and a less steep rise from 03.00 to $05.00 \mathrm{~h}\left(18 \pm 5 \mu \mathrm{mol} \cdot 1^{-1} \cdot \mathrm{min}^{-1}\right.$, $2 p<0.05$ ) during the somatostatin test. Initial plasma non-es-
\end{abstract}

terified fatty acids levels were slightly higher on somatostatin but did not show any statistically significant rise despite arrest of the pump, contrasting with the increase from $491 \pm 27$ to $741 \pm 96 \mu \mathrm{mol} / 1(2 p<0.05)$ in the control test. Consequently, plasma non-esterified fatty acids levels from 01.00 to $05.00 \mathrm{~h}$ were not significantly different between the two tests. The abrupt rise in 3-hydroxybutyrate from 00.00 to $05.00 \mathrm{~h}(3.0 \pm$ $\left.0.5 \mu \mathrm{mol} \cdot 1^{-1} \cdot \mathrm{min}^{-1}\right)$ in the control test was not altered by somatostatin until $03.00 \mathrm{~h}$. In contrast, during the last $2 \mathrm{~h}$ after arrest of the pump, somatostatin inhibited any further rise in 3-hydroxybutyrate levels. In conclusion, somatostatin significantly reduces metabolic deterioration during a 6 -h hocturnal interruption of a continuous subcutaneous insulin infusion. Somatostatin-induced glucagon suppression seems to be involved in reducing hyperglycaemia as well as, together with the somatostatin-induced growth hormone suppression, in the limitation of hepatic ketogenesis in hours 5 and 6 after cessation of insulin supply. In contrast, the early rise in 3-hydroxybutyrate plasma levels is unaffected by somatostatin and thus appears entirely due to the fall in free insulin circulating concentrations.

Key-words: Continuous subcutaneous infusion, Type 1 diabetes, glucagon, growth hormone, insulin, non-esterified fatty acids, pump, somatostatin.
Interruption of continuous subcutaneous insulin infusion (CSII) in diabetic patients without residual insulin secretion is followed by a rapid and sustained increase in blood glucose and plasma 3-hydroxybutyrate levels [1-3]. These metabolic alterations occur in conjunction with an early decrease in plasma free insulin concentrations [2,3] and a later rise in plasma glucagon levels [3]. To investigate the respective roles of insulin deprivation and counter-regulatory hormones in the observed metabolic deterioration, we studied the influence of a somatostatin infusion on the hormonal and metabolic changes observed during a 6-h nocturnal arrest of a CSII pump in seven C-peptide negative Type 1 (insulindependent) diabetic patients.

\section{Material and Methods}

\section{Subjects}

The study was approved by the Ethical Committee for Human Investigations of our Institution and all subjects gave their free and informed consent. Seven Type 1 diabetic patients participated (Table 1). 
Table 1. Clinical characteristics of the patients

\begin{tabular}{|c|c|c|c|c|c|c|c|c|}
\hline Subjects & 1 & 2 & 3 & 4 & 5 & 6 & 7 & Mean $\pm S E M$ \\
\hline Sex & $\mathrm{F}$ & M & M & M & $\mathrm{F}$ & $\mathbf{M}$ & M & \\
\hline Age (years) & 33 & 44 & 53 & 31 & 51 & 41 & 49 & $43 \pm 3$ \\
\hline$\%$ Ideal body weight & 104 & 114 & 119 & 100 & 119 & 92 & 87 & $105 \pm 5$ \\
\hline Duration of diabetes (years) & 12 & 23 & 23 & 28 & 18 & 16 & 7 & $18 \pm 3$ \\
\hline Basal insulin delivery rate $(\mathrm{U} / \mathrm{h})$ & 0.9 & 1.2 & 1.3 & 1.0 & 1.2 & 1.0 & 1.2 & $1.1 \pm 0.1$ \\
\hline Insulin before breakfast (U) & 7 & 9 & 9 & 6 & 12 & 9 & 12 & $9.1 \pm 0.9$ \\
\hline Anti-insulin antibodies (U/1) & 0.82 & 0.07 & 1.32 & 0.10 & 0 & - & 0.35 & $0.44 \pm 0.20$ \\
\hline
\end{tabular}

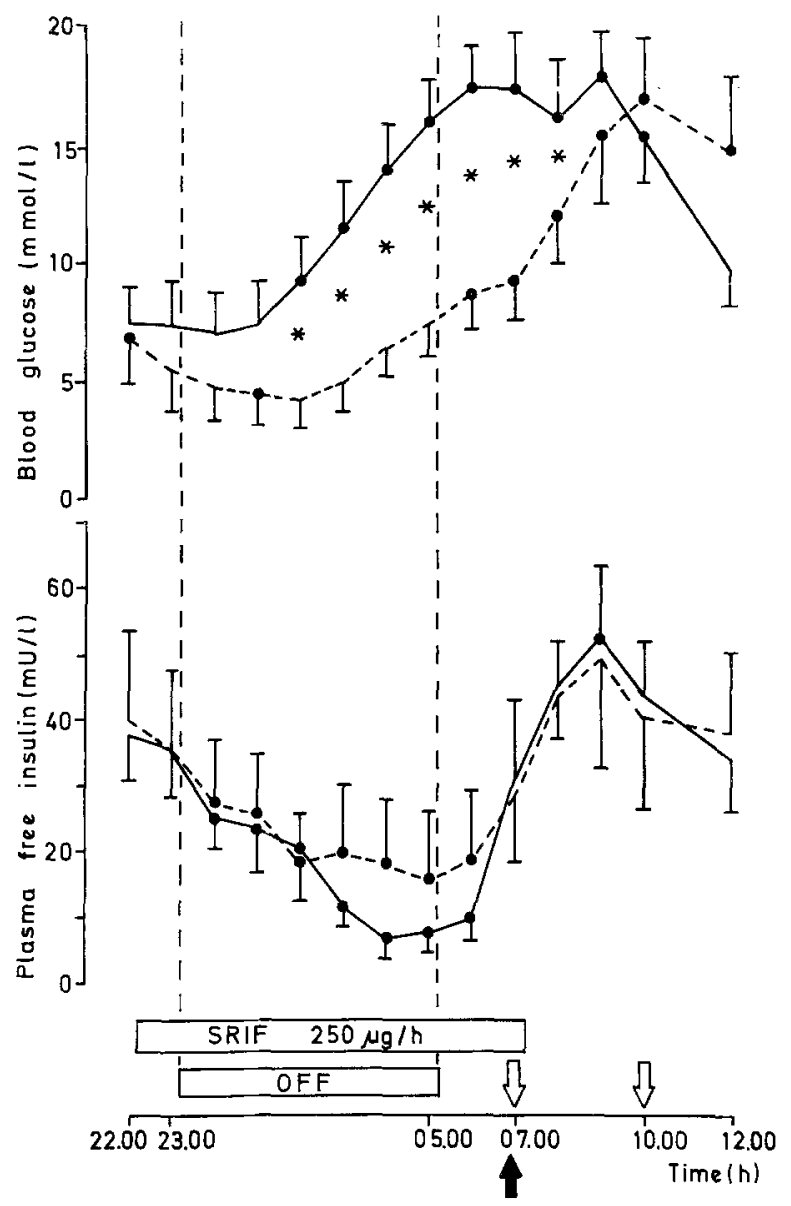

Fig. 1. Changes in blood glucose and plasma free insulin levels before, during and after the interruption of the CSII with (-.-) and without (— ) a somatostatin infusion (SRIF, 250 $\mu \mathrm{g} / \mathrm{h}$ ) in seven Type 1 diabetic patients. Results are expressed as mean \pm SEM. ${ }^{*}=2 p$ $<0.05$ between the two experimental conditions; $=2 p<0.05$ versus $23.00 \mathrm{~h}$ value; $=$ breakfast; $\Delta=$ 'clicks' (boluses of insulin)

The 2-h post-prandial C-peptide plasma concentration was below $0.025 \mathrm{pmol} / \mathrm{ml}$ in all patients.

\section{Experimental Procedure}

The experimental protocol was similar to that in the previous paper [3]. In the present study, each subject underwent two tests in a randomized order: one when the 1001 HM Mill Hill pump was stopped by removing the battery from 23.00 to $05.00 \mathrm{~h}$ and intravenous cyclic somatostatin (Clin Midy, Montpellier, France) infused at a rate of $250 \mu \mathrm{g} / \mathrm{h}$ between 22.00 and $07.00 \mathrm{~h}$ (somatostatin test), the other with an identical interruption of the CSII but with an intravenous infusion of saline instead of somatostatin (control test).

\section{Blood Samples}

Venous blood samples were drawn every hour from 22.00 to $12.00 \mathrm{~h}$ the next day (except at $11.00 \mathrm{~h}$ ). All the metabolic (blood glucose, plasma non-esterified fatty acids, 3-hydroxybutyrate) and hormonal (plasma free insulin, glucagon, growth hormone, cortisol and C-peptide) parameters were determined with the methods mentioned in the previous paper [3]. Plasma glycerol levels were measured according to Eggstein and Kuhlmann [4].

\section{Statistical Evaluation}

The results are expressed as mean \pm SEM. The statistical comparison between the two tests (saline versus somatostatin infusion) was performed according to the Student's t-test for paired values whereas the changes, within a given test, versus the value recorded at $23.00 \mathrm{~h}$ (which was considered as baseline in each test) were analyzed using a two-way analysis of variance followed by the Student's t-test for paired samples.

\section{Results}

\section{Blood Glucose (Fig. 1)}

In the interruption test with saline, blood glucose values remained unchanged during the first $2 \mathrm{~h}$ after arrest of the pump and then increased regularly $(38 \pm 4 \mu \mathrm{mol}$. $1^{-1} \cdot \min ^{-1}$ ) from hour 3 of interruption until $1 \mathrm{~h}$ after resetting the pump at its basal rate $(06.00 \mathrm{~h})$. Despite stopping the pump at $23.00 \mathrm{~h}$, infusion of somatostatin resulted in a decrease in blood glucose concentration until $03.00 \mathrm{~h}(2 p<0.05$ at $01.00 \mathrm{~h})$; four of the seven subjects displayed hypoglycaemic values $<2.5 \mathrm{mmol} / 1$ (see below). Thereafter, blood glucose rose linearly until

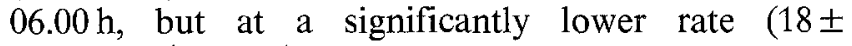
$\left.5 \mu \mathrm{mol} \cdot 1^{-1} \cdot \min ^{-1} ; 2 p<0.05\right)$ than in the control test. Thus, under somatostatin, at the moment of resetting the pump at its basal rate, blood glucose was not significantly different from the $23.00 \mathrm{~h}$ value and markedly lower than the corresponding value in the control test $(7.4 \pm 1.4$ versus $16.0 \pm 1.9 \mathrm{mmol} / 1,2 p<0.001)$. Before breakfast (at $06.45 \mathrm{~h}$ ) blood glucose was $50 \%$ lower than in the control test and, as a consequence, the supplements of insulin together with the usual prebreakfast insulin amounts were reduced $(3.3 \pm 0.9 \mathrm{U}$ after saline versus $1.1 \pm 0.6 \mathrm{U}$ after somatostatin; $2 p<0.025$ ). After breakfast and interruption of the somatostatin infusion at $07.00 \mathrm{~h}$, blood glucose rose rapidly until $10.00 \mathrm{~h}$ $\left(38 \pm 6 \mu \mathrm{mol} \cdot 1^{-1} \cdot \min ^{-1}\right)$, whereas blood glucose levels 


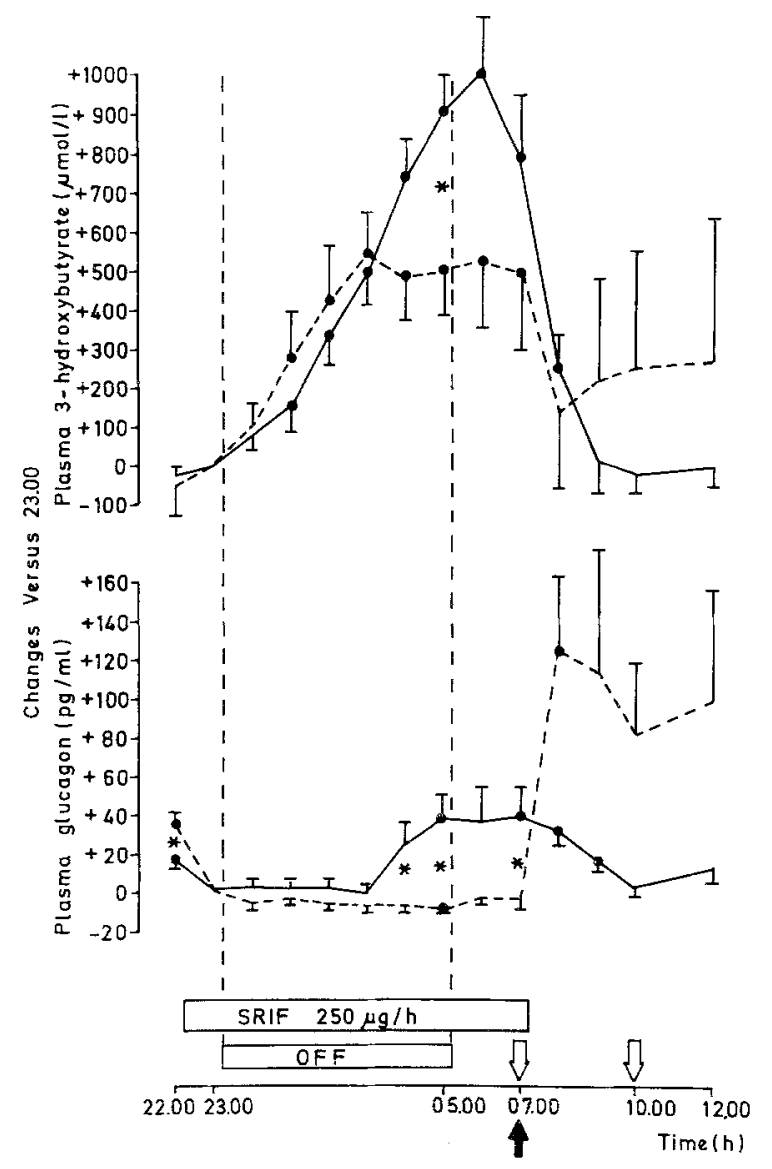

Fig. 2. Changes in plasma 3-hydroxybutyrate and glucagon levels before, during and after the interruption of the CSII with (----) and without $(\longrightarrow$ ) a somatostatin infusion (SRIF, $250 \mu \mathrm{g} / \mathrm{h}$ ) in seven Type 1 diabetic patients. Results (mean \pm SEM) are expressed as changes versus the $23.00 \mathrm{~h}$ value. $*=2 p<0.05$ between the two experimental conditions; $=2 p<0.05$ versus $23.00 \mathrm{~h}$ value; breakfast; $\Delta=$ 'clicks' (boluses of insulin)

remained quite stable during the corresponding period in the control test.

\section{Plasma Free Insulin (Fig. 1)}

No significant differences in plasma free insulin levels were observed between the two tests at any time of the study period. Mean plasma free insulin concentrations were identical at $23.00 \mathrm{~h}(35 \mathrm{mU} / \mathrm{l})$ and decreased significantly as soon as $1 \mathrm{~h}$ after the arrest of the pump in both conditions. However, plasma free insulin levels were slightly but not significantly higher in the somatostatin test reaching $15.5 \pm 10.2 \mathrm{mU} / 1$ with somatostatin and $7.5 \pm 3.1 \mathrm{mU} / 1$ without somatostatin at $05.00 \mathrm{~h}$. Because of the lower blood glucose levels at $6.45 \mathrm{~h}$, the additional amounts of insulin administered before breakfast in the somatostatin test were smaller and the resulting increase in plasma insulin measured from $06.00 \mathrm{~h}$ to $09.00 \mathrm{~h}$ was moderately lower with than without somatostatin $(+27 \pm 10$ versus $+41 \pm 10 \mathrm{mU} / 1,2 p<0.10)$.

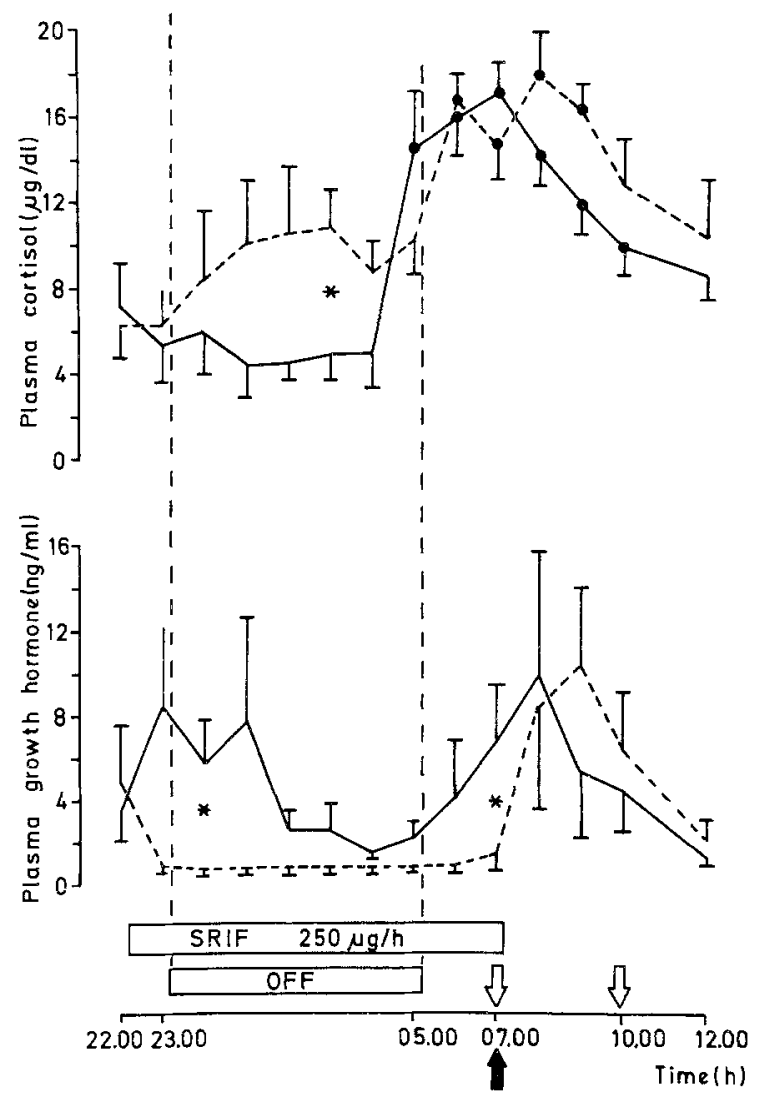

Fig. 3. Changes in plasma cortisol and growth hormone levels before, during and after the interruption of the CSII with (-.--) and without (-) a somatostatin infusion (SRIF, $250 \mu \mathrm{g} / \mathrm{h}$ ) in seven Type 1 diabetic patients. Results are expressed as mean \pm SEM. $*=2 p$ $<0.05$ between the two experimental conditions; $=2 p<0.05$ versus $23.00 \mathrm{~h}$ value; $=$ breakfast; $\Delta=$ 'clicks' (boluses of insulin)

\section{Plasma Glucagon (Fig. 2)}

To eliminate the large inter-individual differences of the glucagon concentrations, results were expressed as changes from the individual value recorded in each subject just before arrest of the pump. With saline infusion, plasma glucagon levels decreased slightly between 22.00 and $23.00 \mathrm{~h}(-16 \pm 3 \mathrm{pg} / \mathrm{ml}, 2 p<0.001)$ and then remained stable until $03.00 \mathrm{~h}$; thereafter, plasma glucagon increased significantly by $40 \mathrm{pg} / \mathrm{ml}$ between 03.00 and $05.00 \mathrm{~h}(2 p<0.05)$, remained stable until $07.00 \mathrm{~h}$ and finally decreased after breakfast and insulin supplements to reach basal values at the end of the study period. In the somatostatin test, plasma glucagon levels were slightly higher at $22.00 \mathrm{~h}$ but dropped immediately after starting the infusion $(-36 \pm 5 \mathrm{pg} / \mathrm{ml}, 2 p<0.001)$ so that absolute glucagon values at $23.00 \mathrm{~h}$ were identical in both conditions $(24 \pm 9 \mathrm{pg} / \mathrm{ml})$. Between 00.00 and $03.00 \mathrm{~h}$, absolute levels of plasma glucagon were significantly lower under somatostatin than under saline infusion ( $18 \pm 4$ versus $26 \pm 4 \mathrm{pg} / \mathrm{ml}, 2 p<0.02)$. In 
Table 2. Plasma non-esterified fatty acids (NEFA) and glycerol levels in the seven patients during the CSII interruption tests carried out with or without somatostatin infusion

\begin{tabular}{|c|c|c|c|c|c|c|c|c|c|}
\hline Time (h) & & 22.00 & 23.00 & 01.00 & 03.00 & 05.00 & 07.00 & 09.00 & 12.00 \\
\hline \multirow[t]{3}{*}{$\begin{array}{l}\text { Plasma NEFA } \\
(\mu \mathrm{mol} / 1)\end{array}$} & $\begin{array}{l}\text { Without } \\
\text { somatostatin }\end{array}$ & $603 \pm 80$ & $491 \pm 27$ & $637 \pm 83$ & $661 \pm 75^{a}$ & $741 \pm 96^{a}$ & $677 \pm 75^{a}$ & $493 \pm 55$ & $521 \pm 101$ \\
\hline & $\begin{array}{l}\text { With } \\
\text { somatostatin } \\
\text { infusion }\end{array}$ & $670 \pm 94$ & $775 \pm 108$ & $721 \pm 116$ & $883 \pm 153$ & $788 \pm 145$ & $927 \pm 135$ & $665 \pm 100$ & $599 \pm 97$ \\
\hline & $2 p$ & NS & $<0.05$ & NS & NS & NS & NS & $<0.05$ & $\mathrm{NS}$ \\
\hline \multirow[t]{3}{*}{$\begin{array}{l}\text { Plasma glycerol } \\
(\mu \mathrm{mol} / \mathrm{l})\end{array}$} & $\begin{array}{l}\text { Without } \\
\text { somatostatin }\end{array}$ & $136 \pm 14$ & $125 \pm 8$ & $120 \pm 5$ & $133 \pm 11$ & $163 \pm 19$ & $153 \pm 22$ & $154 \pm 16$ & $156 \pm 20$ \\
\hline & $\begin{array}{l}\text { With } \\
\text { somatostatin } \\
\text { infusion }\end{array}$ & $130 \pm 10$ & $144 \pm 23$ & $132 \pm 9$ & $114 \pm 16$ & $132 \pm 13$ & $131 \pm 14$ & $136 \pm 8$ & $166 \pm 22$ \\
\hline & $2 p$ & NS & NS & NS & NS & NS & NS & NS & NS \\
\hline
\end{tabular}

Results are given as mean \pm SEM. Statistical analysis used 'anova' following by Student's t-test on paired data versus the $23.00 \mathrm{~h}$ value in a given test ( $\left.{ }^{a} 2 p<0.05\right)$ and Student's t-test on paired samples when comparing values in the two tests (vertical comparison)

this test, plasma glucagon did not exhibit the significant increment from 03.00 to $05.00 \mathrm{~h}$ observed under saline infusion. On the contrary, plasma glucagon progressively decreased and reached its nadir of $15 \pm 8 \mathrm{pg} / \mathrm{ml}$ at $05.00 \mathrm{~h}$. Upon cessation of somatostatin infusion, plasma glucagon displayed an abrupt and marked rise $(+128 \pm 30 \mathrm{pg} / \mathrm{ml}, 2 p<0.01)$ which was sustained until the end of the study period.

\section{Plasma Non-esterified Fatty Acids (NEFA) and Glycerol} (Table 2)

Plasma NEFA levels were similar at $22.00 \mathrm{~h}$ in both tests (Table 2). In the control test, a modest and not statistically significant decrease in plasma NEFA occurred between 22.00 and $23.00 \mathrm{~h}$. Thereafter, following the interruption of CSII, NEFA concentrations rose from $491 \pm 27$ to $741 \pm 96 \mu \mathrm{mol} / 1$ at $05.00 \mathrm{~h}(2 p<0.05)$. In the test carried out under somatostatin infusion, the $23.00 \mathrm{~h}$ level of plasma NEFA was slightly increased but did not show any statistically significant rise despite cessation of insulin infusion. Comparison of plasma NEFA levels between the two tests from 01.00 to $05.00 \mathrm{~h}$ failed to demonstrate any statistically significant difference.

As illustrated in Table 2, plasma glycerol did not display any significant changes during the whole study period and were similar in the two tests at all time intervals.

\section{Plasma 3-Hydroxybutyrate (3-OHB) (Fig. 2)}

As for plasma glucagon, results of 3-OHB determinations were expressed as changes versus the value recorded at $23.00 \mathrm{~h}$. In the test carried out under saline, plasma 3-OHB concentrations were significantly increased $2 \mathrm{~h}$ after arrest of the pump and then rose regularly until $06.00 \mathrm{~h}$. The rate of $3-\mathrm{OHB}$ rise averaged $3.0 \pm 0.5 \mu \mathrm{mol} \cdot 1^{-1} \cdot \mathrm{min}^{-1}$. In the test performed under somatostatin infusion, basal plasma 3-OHB concentrations ( 22.00 and $23.00 \mathrm{~h}$ ) were moderately but not significantly higher when compared with the corresponding values of the control test $(23.00 \mathrm{~h}: 348 \pm 34$ versus $158 \pm 15 \mu \mathrm{mol} / \mathrm{l} ; t=1.67)$. The kinetics of the $3-\mathrm{OHB}$ rise were strictly comparable in both tests during the first four hours after interruption of the CSII. In contrast, from 03.00 to $06.00 \mathrm{~h}$, plasma levels remained remarkably stable in the somatostatin test whereas the rate of increase remained constant in the control test. Consequently, the maximal increase (from 23.00 to $06.00 \mathrm{~h}$ ) was twice higher under saline than under somatostatin infusion. However, since basal 3-OHB levels were higher in the somatostatin test, the absolute concentrations recorded at $05.00 \mathrm{~h}$ were not significantly different.

\section{Plasma Growth Hormone (Fig. 3)}

With infusion of saline, plasma growth hormone levels ranged between 1 and $10 \mathrm{ng} / \mathrm{ml}$ with a tendency to two peaks, the first one between 23.00 and $01.00 \mathrm{~h}$, the second between 07.00 and $09.00 \mathrm{~h}$. Somatostatin completely suppressed growth hormone resulting in growth hormone plasma levels below $1 \mathrm{ng} / \mathrm{ml}$ from 23.00 to $07.00 \mathrm{~h}$. Upon cessation of the somatostatin infusion $(07.00 \mathrm{~h})$, the growth hormone concentrations rapidly reached the level recorded in the control test.

\section{Plasma Cortisol (Fig. 3)}

In the test carried out under saline infusion, plasma cortisol levels exhibited the classical circadian variations with peak values occurring between 05.00 and $07.00 \mathrm{~h}$. During the somatostatin test, the changes in plasma cortisol were similar but a moderate increase was observed already from 00.00 to $03.00 \mathrm{~h}$. 


\section{Metabolic and Hormonal Changes in the Hypoglycaemic Subjects}

The four subjects whose blood glucose levels were below $5 \mathrm{mmol} / \mathrm{l}(3.2 \pm 0.6 \mathrm{mmol} / \mathrm{l}$ at $22.00 \mathrm{~h})$ before starting the somatostatin infusion displayed values below $2.5 \mathrm{mmol} / 1$ from 23.00 to $03.00 \mathrm{~h}$ (nadir $1.8 \pm$ $0.2 \mathrm{mmol} / 1$ at $01.00 \mathrm{~h}$ ) despite interruption of the CSII. When compared to the three other subjects $(8.0 \pm$ $0.7 \mathrm{mmol} / 1$ at $01.00 \mathrm{~h}, 2 p<0.001$ ), the four hypoglycaemic patients exhibited significantly higher plasma cortisol levels $(15.8 \pm 2.5$ versus $2.6 \pm 0.5 \mu \mathrm{g} / \mathrm{dl}$ at $01.00 \mathrm{~h}$, $2 p<0.005)$ and a tendency towards higher plasma free insulin concentrations $(34.0 \pm 11.3$ versus $9.0 \pm$ $2.0 \mathrm{mU} / 1$ at $01.00 \mathrm{~h}, \mathrm{NS}$ ). No significant differences were observed between the two subgroups regarding plasma levels of 3-OHB, NEFA, glycerol, glucagon and growth hormone.

\section{Discussion}

The changes in blood glucose, plasma free insulin, glucagon, NEFA and 3-OHB concentrations during a $6 \mathrm{~h}$ nocturnal interruption of a CSII have been described and discussed in detail in the previous report [3]. In that study as well as in this one, the decrease in plasma free insulin was accompanied by significant rises in plasma concentrations of NEFA and 3-OHB after $2 \mathrm{~h}$, of blood glucose after $3 \mathrm{~h}$ and of plasma glucagon after $5 \mathrm{~h}$. Although the primacy of insulin deprivation is well accepted for explaining the metabolic alterations observed in Type 1 diabetic patients [5, 6], several studies support a significant role of the counter-regulatory hormones, namely glucagon, cortisol, growth hormone and catecholamines [7, 8, review 9].

The most interesting finding of the present study is that a somatostatin infusion which does not significantly influence the fall in plasma free insulin, remarkably prevents the rise in blood glucose and 3-OHB occurring after the interruption of the CSII. An effect of somatostatin on carbohydrate absorption from the gastrointestinal tract [10] can probably be neglected since somatostatin infusion started $4 \mathrm{~h}$ after the last meal. A direct effect of somatostatin on hepatic glucose metabolism remains controversial after studies in vitro, using isolated rat hepatocytes [review 11] as well as investigations carried out in vivo in the dog $[12,13]$. Since somatostatin inhibits the secretion of glucagon and growth hormone, and perhaps under certain circumstances those of ACTH and cortisol [14, 15], the role of these counter-regulatory hormones in the metabolic deterioration observed after arrest of the insulin infusion pump must be discussed.

Our results rule out any participation of plasma cortisol in the prevention of the metabolic decompensation by somatostatin. Indeed, plasma cortisol concentrations remained stable during the interruption of CSII in the control test whereas they were moderately increased in the test carried out under somatostatin infusion. This increase is probably explained by the initial fall in blood glucose since cortisol response to hypoglycaemia is not modified by somatostatin [16].

In agreement with previous studies, somatostatin depressed basal levels of growth hormone by more than $50 \%[7,17]$ and remarkably suppressed its nocturnal peaks $[18,19]$. The studies of Gerich et al. [8], in which an infusion of growth hormone during suppression of its endogenous secretion reproduced physiological hormone levels, demonstrates the absence of significant metabolic changes in presence of insulin. However, after insulin was withdrawn, plasma NEFA, glycerol and 3-OHB all rose higher than in the test with somatostatin but without growth hormone; simultaneously no effect on blood glucose was detected. These data thus indicate that physiological levels of growth hormone are lipolytic and ketogenetic in the absence of insulin. Consequently, as insulin deprivation progresses, the suppression of growth hormone could be responsible at least in part for the reduced rises in plasma NEFA and 3-OHB observed after arrest of the pump. On the contrary, the failure of growth hormone to alter blood glucose [8] suggests that it is not involved in the somatostatin-induced prevention of hyperglycaemia.

As expected, somatostatin induced a significant decrease in plasma glucagon levels $[7,14,17]$. This inhibition which was already detectable on the basal glucagon levels from 23.00 until $03.00 \mathrm{~h}$ became more obvious from 04.00 to $07.00 \mathrm{~h}$ when the late and significant glucagon rise observed in the control test was completely suppressed by somatostatin. In this respect, the $6 \mathrm{~h}$ of CSII interruption can be divided in two periods: (1) During the first $4 \mathrm{~h}$, basal glucagon secretion is moderately but significantly reduced; simultaneously, the abrupt rise in 3-OHB is not altered but the increase in blood glucose is fully suppressed, a tendency towards hypoglycaemia being observed. (2) During the last $2 \mathrm{~h}$, the inhibition of glucagon is accompanied by a complete blockade of the rise in 3-OHB levels. During the corresponding period, the increase in blood glucose was clearly slowed when compared with that of the control test despite a severe insulin deficiency.

Our results agree with those of Gerich et al. [7] concerning the evolution of blood glucose but partially differ as far as changes in 3-OHB levels are concerned. Indeed, in Gerich's study, the precocious rise in 3-OHB following the interruption of an intravenous insulin infusion was suppressed at once when somatostatin was infused at a rate of $500 \mu \mathrm{g} / \mathrm{h}$. This difference could be attributed to: (1) the more rapid insulin deprivation occurring after cessation of an intravenous rather than a subcutaneous insulin administration, (2) the earlier rise in plasma glucagon secondary to the acute fall in circulating insulin and (3) the twice higher rate of somatostatin infusion. 
Our results can be related to the differences reported by Barnes et al. [20] between patients with juvenile-type diabetes who showed a sharp rise in plasma glucagon levels after interruption of an intravenous insulin infusion and totally pancreatectomized subjects whose plasma glucagon remained undetectable. During the first $6 \mathrm{~h}$ following cessation of insulin delivery, the increase in blood glucose was $100 \%$ steeper in the juvenile-type diabetic patients than in the pancreatectomized subjects, although the rise in plasma 3-OHB was similar in the two groups. Later, the rise in 3-OHB became significantly steeper in the group with persistent glucagon secretion whereas a tendency to a plateau was noticed in the group without residual glucagon secretion. Consequently, we suggest that the changes in blood glucose under somatostatin infusion in our study are best explained by suppression of glucagon secretion presumably via an inhibition of hepatic glucose production. This interpretation is in agreement with previous data in somatostatin-infused depancreatectomized dogs [21] as well as in insulin- and somatostatin-infused normal men with selective glucagon deficiency [22]. As far as 3OHB is concerned, the initial increase (first $4 \mathrm{~h}$ ) appears secondary to the decrease in free insulin circulating levels and independent of circulating glucagon since, at this period of the study, this rise in 3-OHB is unaffected by somatostatin despite a modest but significant glucagon suppression. On the contrary, the ongoing increase in ketogenesis which occurs under saline infusion between hours 4 and 6 of the test seems dependent at least in part upon the late glucagon rise since it is entirely blocked by somatostatin infusion. This view is in agreement with the current theory on the role of glucagon in ketogenesis as recently reviewed by McGarry and Foster [23]. In addition, the somatostatin-induced reduction in ketogenesis could be partly mediated by inhibition of growth hormone secretion, particularly in a state of insulin deprivation as observed from hours 4-6 after arrest of the CSII $[8,24,25]$.

In conclusion, intravenous somatostatin, at a dose of $250 \mu \mathrm{g} / \mathrm{h}$, significantly reduces metabolic deterioration during a $6 \mathrm{~h}$ nocturnal interruption of a CSII. Somatostatin-induced glucagon suppression seems to be involved in the reduction of hyperglycaemia which occurs on interruption of CSII as well as, together with growth hormone, in the limitation of hepatic ketogenesis in hours 5 and 6 after cessation of the subcutaneous insulin infusion. In contrast, the early rise in 3-OHB levels is not affected by somatostatin and is apparently entirely due to the fall in free insulin circulating levels.

\footnotetext{
Acknowledgments. This study was supported by grants of the Fonds National de la Recherche Scientifique and the Fonds de la Recherche Scientifique Médicale of Belgium. We thank the patients who volunteered for this study. We acknowledge the skilful technical assistance of C. Cartenstadt, Y.Claessens, M. Marchand, C. Borremans, A. Rombaux, M.E. Loumaye and R. Lallemand and the expert secretarial help of E. Vaessen-Petit. M.C. is on leave from the University of Granada, Spain.
}

\section{References}

1. Champion MC, Shepherd GAA, Rodger NW, Dupre J (1980) Continuous subcutaneous infusion of insulin in the management of diabetes mellitus. Diabetes 29: 206-212

2. Pickup JC, Viberti GC, Bilous RW, Keen H, Alberti KGMM, Home PD, Binder C (1982) Safety of continuous subcutaneous insulin infusion: metabolic deterioration and glycaemic autoregulation after deliberate cessation of infusion. Diabetologia 22: 175-179

3. Krzentowski G, Scheen A, Castillo M, Luyckx AS, Lefèbvre PJ (1983) A 6-hour nocturnal interruption of a continuous subcutaneous insulin infusion: 1. Metabolic and hormonal consequences and scheme for a prompt return to adequate control. Diabetologia 24: $314-318$

4. Eggstein M, Kuhlmann E (1974) Triglycerides and glycerol determination after alkaline hydrolysis. In: Bergmeyer HU (ed) Methods of enzymatic analysis, vol.4, Academic Press, London, pp 1825-1831

5. Felig P, Wahren J, Sherwin R, Hendler R (1976) Insulin, glucagon and somatostatin in normal physiology and diabetes. Diabetes 25: 1091-1096

6. Vaisrub S (1976) Editorial: the primacy of insulin. JAMA 236: 1274-1275

7. Gerich JE, Lorenzi M, Bier DM, Schneider V, Tsalikian E, Karam JH, Forsham PH (1975) Prevention of human diabetic ketoacidosis by somatostatin. Evidence for an essential role of glucagon. $\mathrm{N}$ Engl J Med 292: 985-989

8. Gerich JE, Lorenzi M, Bier DM, Tsalikian E, Schneider V, Karam JH, Forsham PH (1976) Effects of physiologic levels of glucagon and growth hormone on human carbohydrate and lipid metabolism. Studies involving administration of exogenous hormone during suppression of endogenous hormone secretion with somatostatin. J Clin Invest 57: 875-884

9. Schade DS, Eaton RP (1977) The controversy concerning counterregulatory hormone secretion. A hypothesis for the prevention of diabetic ketoacidosis? Diabetes 26: 596-601

10. Wahren J, Felig P (1976) Influence of somatostatin on carbohydrate disposal and absorption in diabetes mellitus. Lancet 2: $1213-1216$

11. Canivet B, Le Cam A, Freychet P (1979) Somatostatin: lack of effect on cyclic AMP release and amino acid transport in isolated rat hepatocytes. Diab Metab 5: 17-19

12. Cherrington AD, Chiasson JL, Liljenquist JE, Jennings AS, Keller U, Lacy WW (1976) The role of insulin and glucagon in the regulation of basal glucose production in the post-absorptive dog. $\mathrm{J}$ Clin Invest 58: 1407-1418

13. Blauth CIA, Sonksen PH, Tompkins CV, Bloom SR (1977) The hypoglycaemic action of somatostatin in the anaesthetized dog. Clin Endocrinol (Oxf) 6: 17-25

14. Guillemin R, Gerich JE (1976) Somatostatin: physiological and clinical significance. Ann Rev Med 27: 379-388

15. Lundbaek K, Hansen AaP, Ørskov H, Christensen SE, Iversen J, Seyer-Hansen K, Alberti KGMM, Whitefoot R (1976) Failure of somatostatin to correct manifest diabetic ketoacidosis. Lancet 1: 215-218

16. Copinschi $\mathrm{G}$, Virasoro E, Vanhaelst L, Leclereq R, Golstein J, L'Hermite M (1974) Specific inhibition by somatostatin of growth hormone release after hypoglycaemia in normal man. Clin Endocrinol (Oxf) 3: 441-445

17. Luyckx AS, Lefèbvre PJ (1976) Effect of somatostatin on metabolic and hormonal changes induced by nicotinic acid in insulin-dependent diabetics. Diabetologia 12: 447-453

18. Ward FR, Leblanc H, Yen SSC (1975) The inhibitory effect of somatostatin on growth hormone, insulin and glucagon secretion in diabetes mellitus. J Clin Endocrinol Metab 41: 527-532

19. Parker DC, Rossman LG, Siler TM, Rivier J, Yen SSC, Guillemin $\mathrm{R}$ (1974) Inhibition of the sleep-related peak in physiological human growth hormone release by somatostatin. J Clin Endocrinol Metab 38: 496-499 
20. Barnes AJ, Bloom SR, Alberti KGMM, Smythe P, Alford FP, Chisholm DJ (1977) Ketoacidosis in pancreatectomized man. New Engl J Med 296: 1250-1253

21. Vranic M, Yip C, Doi K, Lickley L, Morita S, Ross G (1977) Insulin and glucagon (pancreatic and extrapancreatic) interactions and the regulation of glucose turnover in physiology and in the diabetic state. In: Foà PP, Bajaj JS, Foà NL (eds) Glucagon: its role in physiology and clinical medicine, Springer-Verlag, NewYork, pp 403-436

22. Liljenquist JE, Mueller GL, Cherrington AD, Keller U, Chiasson JL, Perry JM, Lacy WW, Rabinowitz D (1977) Evidence for an important role of glucagon in the regulation of hepatic glucose production in normal man. J Clin Invest 59: 369-374

23. McGarry JD, Foster DW (1980) Regulation of hepatic fatty acid oxidation and ketone body production. Ann Rev Biochem 49: $395-420$

24. Schade DS, Eaton RP, Peake GT (1978) The regulation of plasma ketone body concentration by counterregulatory hormones in man. II. Effect of growth hormone in diabetic man. Diabetes 27: 916-924

25. Johnston DG, Alberti KGMM, Gill A, Metcalfe P, Ørskov H (1980) The roles of glucagon and growth hormone in basal glucose homeostasis and ketogenesis. In: Andreani D, Lefèbvre PJ, Marks $\mathrm{V}$ (Eds) Current views on hypoglycemia and glucagon, Academic Press, New York, pp 107-115

Received: 13 June 1982

and in revised form: 2 November 1982

Dr. P.J. Lefèbvre

Institut de Médecine

Hôpital de Bavière

Boulevard de la Constitution, 66

B-4020 Liège

Belgium 